\title{
SEWAGE SLUDGE APPLICATION ON CULTIVATED SOILS: EFFECTS ON RUNOFF AND TRACE METAL LOAD
}

\author{
Marcelo Valadares Galdos ${ }^{1}$; Isabella Clerici De Maria ${ }^{2 *}$; Otávio Antonio de Camargo ${ }^{2}$; Sonia \\ Carmela Falci Dechen ${ }^{2}$ \\ ${ }^{1}$ USP/CENA, Av. Centenário, 303 - 13400-970 - Piracicaba, SP - Brasil. \\ ${ }^{2}$ IAC - Centro de Solos e Recursos Ambientais, C.P. 28 - 13020-902 - Campinas, SP - Brasil. \\ *Corresponding author <icdmaria@iac.sp.gov.br>
}

\begin{abstract}
The use of sewage sludge in agricultural soils as a macro and micronutrient source and as a soil conditioner has been one of the alternatives for its disposal. However, sewage sludge contains trace metals, which are potential sources of pollution. The goal of this study was to evaluate the effect of sewage sludge application on surface water contamination through runoff when it was applied in a soil cultivated with corn. The effect of sludge application on the concentration and load of copper, nickel and zinc and the volume of runoff water and sediment were evaluated. The experiment was set up in plots used to study erosion losses in Campinas, Sao Paulo State, Brazil. The soil is a clayey Rhodic Hapludox. Three treatments were studied: no sewage sludge, sewage sludge to supply the $\mathrm{N}$ required by the crop and twice that amount, with four replications. The water and sediment lost by runoff were measured after each rainfall, and sampled for chemical analysis. The volumes of water and sediment lost by runoff decreased after sewage sludge application. The waste application increased trace metal concentration in the runoff water and sediment, especially zinc, which was present in high concentration in the sewage sludge used. Nevertheless, the load of trace metals transported from the plot was mostly dependent on the total runoff volume. Most of the $\mathrm{Cu}, \mathrm{Zn}$ and $\mathrm{Ni}$ losses were via sediment, and occurred in a few highly erosive rainfall events in the period studied.
\end{abstract}

Key words: $\mathrm{Cu}, \mathrm{Ni}, \mathrm{Zn}$, erosion, sediment

\section{APLICAÇÃO DE LODO DE ESGOTO EM SOLOS AGRÍCOLAS: EFEITOS NA ENXURRADA E NO CARREAMENTO DE METAIS}

\begin{abstract}
RESUMO: O uso de lodo de esgoto em solos agrícolas como fonte de macro e micronutrientes e como condicionador de solos tem sido uma das alternativas para sua disposição final. O lodo de esgoto, entretanto, contém metais que são potencialmente fonte de poluição. Estudou-se o efeito da aplicação de lodo de esgoto na contaminação de águas superficiais por meio da enxurrada proveniente de solo agrícola cultivado com milho. O efeito da aplicação do lodo na concentração e no carreamento de cobre, níquel e zinco e no volume de enxurrada e sedimentos foi avaliado. Os tratamentos foram aplicados em parcelas utilizadas para estudos de perdas por erosão em Campinas, São Paulo, Brasil. O solo era um Latossolo Vermelho férrico argiloso. Os três tratamentos foram: sem lodo, com lodo para suprir o $\mathrm{N}$ requerido pela cultura e duas vezes essa quantidade, com quatro repetições. A água e o sedimento perdidos pela enxurrada eram medidos na manhã seguinte de cada chuva e amostrados para análise química. Os volumes de água e de sedimentos perdidos por enxurrada diminuíram com a aplicação do lodo. A aplicação do resíduo aumentou a concentração de metais na água e no sedimento, especialmente do zinco que estava presente em alta concentração do lodo de esgoto utilizado. Entretanto, a carga de metais transportados das parcelas foi dependente principalmente do volume total de enxurrada. A maior parte das perdas de $\mathrm{Cu}, \mathrm{Ni}$ e $\mathrm{Zn}$ foi via sedimento e ocorreu em alguns poucos eventos de alta erosividade no período de estudo.

Palavras-chave: $\mathrm{Cu}, \mathrm{Ni}, \mathrm{Zn}$, erosão, sedimento
\end{abstract}

\section{INTRODUCTION}

Application of sewage sludge in agricultural soils as an organic conditioner and fertilizer has grown in Brazil, driven by a significant increase in the volume of sewage treated in the country. Sewage sludge can behave as a soil conditioner due to the role of or- ganic matter in improving soil structure, by increasing aggregate resistance, reducing soil density and increasing soil porosity (Elliot, 1986; Jorge et al., 1991; Wilson et al., 1996; Navas et al., 1998). Therefore, sewage sludge application is expected to increase water infiltration and reduce soil water erosion (Aguilar \& Loftin, 1991; Joshua et al., 1998; Harris-Pierce et 
al., 1995; Kelling et al., 1977; Kladivko \& Nelson, 1979; Mostaghimi et al., 1989; Bossche et al., 2000). However, sewage sludge has a variable content of trace metals (Berton, 2000) which could accumulate in the soil and be transported by runoff water and sediment, contaminating surface waters (Evangelou, 1998).

Water erosion is one of the main causes of the pollution of water bodies and one of the main reasons of soil degradation in Brazil, where erosion losses in agricultural soils were estimated to be close to 20 t ha $^{-1}$ year $^{-1}$ (Bertoni \& Lombardi Neto, 1990). Trace metals are transported into runoff both diluted in the water and/or adsorbed to the clay and organic matter colloidal particles (Quinton, 2001). Therefore, although sewage sludge application might reduce erosion, contamination by trace metals can occur on deposition areas.

The objectives of this study were to determine: i) the effect on the water and sediment losses by surface runoff of two consecutive sewage sludge applications on a clayey Haplortox soil cultivated with corn, as a function of the intensity and distribution of rainfall, and ii) the load of trace metals in these water and sediment in order to evaluate the potential diffuse pollution as a result of the sewage sludge application.

\section{MATERIAL AND METHODS}

The experiment was carried out in Campinas,

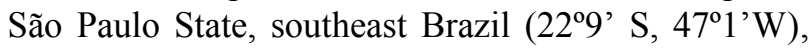
in the 2001/2002 and 2002/2003 agricultural seasons. Permanent sloped plots with runoff catchment paved boxes were used. The plots have $100 \mathrm{~m}^{2}(4 \times 25 \mathrm{~m})$ area, with a uniform slope of $10 \%$, and have cemented borders. The soil is a Typic Haplortox, clayey $(0.65 \mathrm{~g}$ $\mathrm{g}^{-1}$ of clay) in texture and has an erodibility index of $0.0122 \mathrm{t}$ ha $\mathrm{h} \mathrm{MJ}^{-1} \mathrm{ha}^{-1} \mathrm{~mm}^{-1}$ (Lombardi Neto \& Bertoni, 1975). Some of the physical and chemical properties of the soil is presented on Table 1 .

The climate in the region is a Cwa type according to the Köppen classification (Critchfield, 1960), defined as humid tropical with a rainy summer and dry winter. The mean annual temperature is $20.5^{\circ} \mathrm{C}$ and the mean annual rainfall is $1,400 \mathrm{~mm}$, with $76 \%$ of the precipitation between October and March (data collected in the weather station adjacent to the experi- mental plots). The mean annual erosivity is $6,738 \mathrm{MJ}$ $\mathrm{mm} \mathrm{ha} \mathrm{h}^{-1} \mathrm{~h}^{-1}$ year $^{-1}$ (Lombardi Neto \& Moldenhauer, 1992).

The runoff catchment systems installed at the end of the plots are composed of rotating metal trays subdivided into two one-litter compartments. These trays are connected to a counting device, which makes it possible to monitor the quantity of water lost by surface runoff. After filling the tray, the runoff water falls into an impermeable concrete box, where water and sediment can be quantified and collected for chemical analysis.

Every morning following a sediment-producing rainfall event the volume of water and sediment in the collecting boxes were measured. Water samples were also taken from a pluviometer located at the study area, as a blank sample. Two subsamples were taken from each water sample. A $50 \mathrm{~mL}$ subsample was used for $\mathrm{pH}$ determination. The second subsample, $100 \mathrm{~mL}$, was left to settle for $24 \mathrm{~h}$ with $2 \mathrm{~mL}$ of $\mathrm{HNO}_{3}$ at $65 \%(\mathrm{~m} / \mathrm{v})$. After the settling period, the sample was filtered through blue stripe slow filtration paper Whatman 42 filter - and refrigerated for the chemical analyses. The $\mathrm{Cu}, \mathrm{Ni}$ and $\mathrm{Zn}$ determination in the runoff water were performed in an argon emission spectrometer (ICP-OES), in the following spectral lines: $\mathrm{Cu}$ $=324.754, \mathrm{Ni}=231.604$ and $\mathrm{Zn}=213.856 \mathrm{~nm}$. The whole volume of sediment contained in the boxes was collected, air dried, sieved in a $2 \mathrm{~mm}$ sized sieve and stored for chemical analysis of both available (Raij et al., 2001) and total EPA (Abreu et al., 2001) metal content.

The experiment was designed with three treatments, L0, L1 and L2, equivalent to sewage sludge application rates of $0,10.8$ and $21.6 \mathrm{Mg}$ of dry matter per hectare, corresponding to 0,1 and 2 times the $\mathrm{N}$ requirement of corn with four replications. The 10.8 $\mathrm{Mg} \mathrm{ha}^{-1}$ rate was determined based on the chemical analysis of the sewage sludge and the nitrogen recommendation for corn (CETESB, 1999). The sewage sludge was manually incorporated to a $0.10 \mathrm{~m}$ depth, in December 2001 and November 2002. An NPK fertilizer was applied at planting date in the control treatment, without sludge application; and potassium in the form of potassium chloride was applied in the plots receiving sewage sludge.

Table 1 - Physical and chemical soil properties of Typic Haplortox before experiment, on surface layer.

\begin{tabular}{|c|c|c|c|c|c|c|c|c|c|c|}
\hline Sand & Silt & Clay & $\mathrm{Bd}$ & CEC & BS & $\mathrm{Ca}$ & $\mathrm{OM}$ & $\mathrm{P}$ & $\mathrm{Fe}$ & $\begin{array}{c}\mathrm{pH} \\
\mathrm{CaCl}_{2}\end{array}$ \\
\hline$-\ldots$ & $\mathrm{g} \mathrm{kg}^{-}$ & ---- & $\mathrm{Mg} \mathrm{m}^{-3}$ & $-\cdots---$ & $\mathrm{mmol}_{\mathrm{c}} \mathrm{c}$ & - - - - & $\mathrm{g} \mathrm{dm}^{-3}$ & -...- & $\mathrm{mg} \mathrm{dm}$ & - \\
\hline 287 & 132 & 581 & 1.21 & 61.3 & 16.4 & 10 & 18 & 20 & 21.2 & 4.6 \\
\hline
\end{tabular}

$\mathrm{Bd}=$ bulk density; $\mathrm{CEC}=$ cation exchange capacity, $\mathrm{Ca}=$ calcium; $\mathrm{BS}=$ base saturation; $\mathrm{OM}=$ organic matter; $\mathrm{P}=$ phosphorus; Fe = iron 
The sewage sludge used was provided by the Sewage Treatment Plant of Jundiai, Sao Paulo State, Brazil. The main chemical parameters of the sewage sludge are presented in Table 2. The elements, with exception for carbon and nitrogen, were extracted by the EPA 3051 method (Abreu et al., 2001) and determined by ICP-OES. The organic carbon was extracted by the digestion block method, and determined by titration. The volatile solids determination was done by weighting a $2.5 \mathrm{~g}$ sample dried at $60^{\circ} \mathrm{C}$, incinerating it in a $500^{\circ} \mathrm{C}$ muffle for $4 \mathrm{~h}$ and weighting it again. The total $\mathrm{N}$ (Kjeldahl method), $\mathrm{NH}_{4}^{+}$and $\mathrm{NO}_{3}^{-}$determination was performed by the Cantarella \& Trivelin (2001) method. The sample in the original conditions was used to determine the nitrogen concentration in the ammonium and nitric forms.

The corn crop was planted in contour lines, with $0.90 \mathrm{~m}$ spacing, and five plants per meter, on December 2001 and November 2002. The control plots, with no sewage sludge application (L0), were fertilized at planting with a NPK formula, containing $4.8 \mathrm{~kg} \mathrm{ha}^{-1} \mathrm{~N}, 21 \mathrm{~kg} \mathrm{ha}^{-1} \mathrm{P}$ and $14.5 \mathrm{~kg} \mathrm{ha}^{-1} \mathrm{~K}$. Due to the low concentration of potassium in the sewage sludge, potassium chloride was applied in the plots receiving the residue (L1 and L2), at the same rate as the control plot, $14.5 \mathrm{~kg} \mathrm{ha}^{-1} \mathrm{~K}$. Nitrogen fertilizer dressing applications were applied in January 2002, as $165 \mathrm{~kg} \mathrm{ha}^{-1}$ urea in the L0 treatment, and as $180 \mathrm{~kg} \mathrm{ha}$ ${ }^{1}$ urea in all three treatments in January 2003. The crop was harvested in May 2002 and April 2003.

Correlations between runoff and rainfall volumes and between runoff and erosivity index were tested. The erosivity index used was the $\mathrm{EI}_{30}$ index, as defined by Wischmeier \& Smith (1978), calculated by total storm kinetic energy (E) times maximum 30minutes intensity $\left(\mathrm{I}_{30}\right)$. Results were submitted to analysis of variance with $\mathrm{F}$ test application $(p<0.05)$, using the GLM procedure of the SAS program (SAS INSTITUTE, 1997). The treatment means were compared by applying the " $\mathrm{t}$ " test at 0.05 significance.

\section{RESULTS AND DISCUSSION}

\section{Runoff volume}

During the two-year period 120 rainfall events were evaluated, 54 in 2001/2002 and 66 in 2002/2003. Water runoff losses in the first 180 days after the sewage sludge application are presented in Table 3, divided in 30-day periods. There was a reduction of 31 and $38 \%$ in runoff water in the L1 and L2 treatments, respectively, compared to the plots without sludge application. These results are very close to those of 38 and $32 \%$ reduction in runoff water observed by Mostaghimi et al. (1989) with a rain simulator, comparing two rates of sludge to a control plot without sludge. In both years of this study, over $50 \%$ of the runoff water losses happened in the first two months after the sewage sludge application. Under this climate and agricultural system, this initial period is critical regarding to runoff losses, due to the high rainfall intensity and the low soil cover by the crop.

The runoff water was proportional to the rainfall volume, following a second degree polynomial model (Figure 1a). The values dispersion was more pronounced for the control than for L1 and L2 treatments. The slope of the curve diminished when sewage sludge rate increased. Similar results were founded in an experiment with sewage sludge application using runoff plots, with a steeper curve in the control plot and little difference between the rates of sewage sludge applied (Joshua et al., 1998).

Table 2 - Average concentration of the elements, $\mathrm{pH}$ and water content in the sewage sludge applied in 2001 and 2002.

\begin{tabular}{|c|c|c|c|c|c|}
\hline Parameter & Unit & Value & Parameter & Unit & Value \\
\hline Aluminum & $\mathrm{mg} \mathrm{kg}^{-1}$ & 17.6 & Manganese & $\mathrm{mg} \mathrm{kg}^{-1}$ & 685.0 \\
\hline Arsenic & $\mathrm{mg} \mathrm{kg}^{-1}$ & $<0.01$ & Mercury & $\mathrm{mg} \mathrm{kg}^{-1}$ & $<0.01$ \\
\hline Boron & $\mathrm{mg} \mathrm{kg}^{-1}$ & 12.0 & Nickel & $\mathrm{mg} \mathrm{kg}^{-1}$ & 38.7 \\
\hline Cadmium & $\mathrm{mg} \mathrm{kg}^{-1}$ & 6.2 & Nitrogen - $\mathrm{NH}_{4}$ & $\mathrm{mg} \mathrm{kg}^{-1}$ & 507.8 \\
\hline Calcium & $\mathrm{g} \mathrm{kg}^{-1}$ & 11.1 & Nitrogen - Kjeldahl & $\mathrm{g} \mathrm{kg}^{-1}$ & 27.7 \\
\hline Organic Carbon & $\mathrm{g} \mathrm{kg}^{-1}$ & 312.0 & Nitrogen $-\mathrm{NO}_{2} \mathrm{NO}_{3}$ & $\mathrm{mg} \mathrm{kg}^{-1}$ & 87.9 \\
\hline Lead & $\mathrm{mg} \mathrm{kg}^{-1}$ & 244.8 & $\mathrm{pH}$ & & 6.0 \\
\hline Copper & $\mathrm{mg} \mathrm{kg}^{-1}$ & 574.5 & Potassium & $\mathrm{g} \mathrm{kg}^{-1}$ & 1.3 \\
\hline Total Chromium & $\mathrm{mg} \mathrm{kg}^{-1}$ & 168.9 & Selenium & $\mathrm{mg} \mathrm{kg}^{-1}$ & $<0.01$ \\
\hline Sulphur & $\mathrm{g} \mathrm{kg}^{-1}$ & 26.4 & Sodium & $\mathrm{g} \mathrm{kg}^{-1}$ & 1.3 \\
\hline Iron & $\mathrm{g} \mathrm{kg}^{-1}$ & 25.1 & Volatile Solids & $\%$ & 56.0 \\
\hline Phosphorus & $\mathrm{g} \mathrm{kg}^{-1}$ & 6.9 & Water & $\%$ & 66.9 \\
\hline Magnesium & $\mathrm{g} \mathrm{kg}^{-1}$ & 1.9 & Zinc & $\mathrm{mg} \mathrm{kg}^{-1}$ & 1551.4 \\
\hline
\end{tabular}


Table 3 - Rainfall and runoff volume for 30-day periods following the annual sludge application at the rates of 0 (L0), 10.2 (L1) and 20.5 (L2) Mg ha ${ }^{-1}$ in 2001/2002 and 2002/2003.

\begin{tabular}{|c|c|c|c|c|c|}
\hline \multirow{2}{*}{$\begin{array}{l}\text { Period } \\
2001 / 2002\end{array}$} & \multirow{2}{*}{ Number of events } & \multirow{2}{*}{ Rainfall } & \multicolumn{3}{|c|}{ Runoff volume } \\
\hline & & & L0 & L1 & L2 \\
\hline days & & $\mathrm{mm}$ & - & $\mathrm{n}^{3} \mathrm{ha}^{-1}-$. & - \\
\hline $0-30$ & 16 & 256.3 & $78.8 \mathrm{a}^{\dagger}$ & $36.5 \mathrm{~b}$ & $37.2 \mathrm{~b}$ \\
\hline $30-60$ & 14 & 177.1 & $23.6 \mathrm{a}$ & $20.7 \mathrm{a}$ & $19.4 \mathrm{a}$ \\
\hline $60-90$ & 8 & 94.8 & $8.4 \mathrm{a}$ & $8.7 \mathrm{a}$ & $8.3 \mathrm{a}$ \\
\hline $90-120$ & 7 & 109.7 & $10.5 \mathrm{a}$ & $10.9 \mathrm{a}$ & $9.3 \mathrm{a}$ \\
\hline $120-150$ & 6 & 42.1 & $5.2 \mathrm{a}$ & $4.8 \mathrm{a}$ & $4.6 \mathrm{a}$ \\
\hline $150-180$ & 3 & 59.0 & $9.2 \mathrm{a}$ & $7.9 \mathrm{a}$ & $6.8 \mathrm{a}$ \\
\hline Total & 54 & 739.0 & $135.7 \mathrm{a}$ & $89.4 \mathrm{a}$ & $85.5 \mathrm{a}$ \\
\hline \multicolumn{6}{|l|}{$2002 / 2003$} \\
\hline $0-30$ & 12 & 210.0 & $75.2 \mathrm{a}$ & $61.9 \mathrm{a}$ & $47.5 \mathrm{a}$ \\
\hline $30-60$ & 14 & 269.0 & $66.9 \mathrm{a}$ & $39.4 \mathrm{~b}$ & $38.4 \mathrm{~b}$ \\
\hline $60-90$ & 16 & 242.0 & $54.2 \mathrm{a}$ & $34.9 \mathrm{~b}$ & $31.6 \mathrm{~b}$ \\
\hline $90-120$ & 13 & 224.4 & $59.5 \mathrm{a}$ & $41.4 \mathrm{a}$ & $37.5 \mathrm{a}$ \\
\hline $120-150$ & 5 & 44.1 & $4.1 \mathrm{a}$ & $4.2 \mathrm{a}$ & $4.1 \mathrm{a}$ \\
\hline $150-180$ & 6 & 67.4 & $6.3 \mathrm{a}$ & $6.2 \mathrm{a}$ & $6.5 \mathrm{a}$ \\
\hline Total & 66 & 1056.9 & $266.2 \mathrm{a}$ & $188.0 \mathrm{a}$ & $165.6 \mathrm{a}$ \\
\hline
\end{tabular}

'Mean values followed by the same letter are not different $(p<0.05)$.
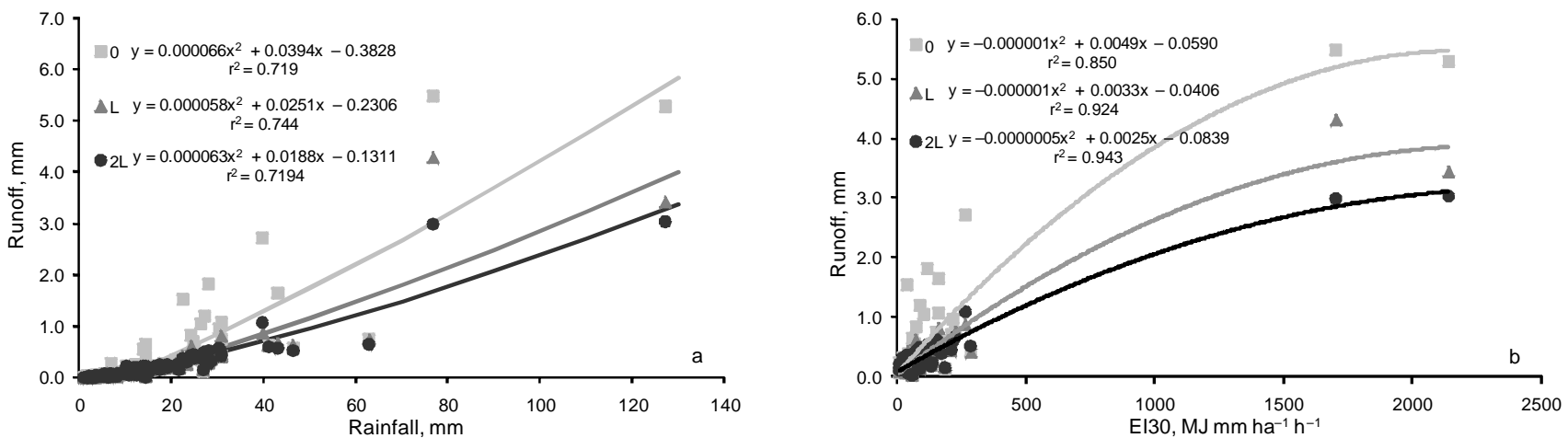

Figure 1 - Runoff water as a function of (a) rainfall volume, (b) $\mathrm{EI}_{30}$ index, in the sewage sludge application rates of 0 (L0), 10.2 (L1) and 20.5 (L2) $\mathrm{Mg} \mathrm{ha}^{-1}$. (All equations in ANOVA Ftest resulted significant $(p<0.01)$.

There was a significant correlation between runoff volume and the $\mathrm{EI}_{30}$ erosivity index (Figure 1b), although this index has been developed as a soil loss related parameter (Wischmeier \& Smith, 1978). Based on the relationship between the runoff volume and the $\mathrm{EI}_{30}$ index, the runoff volume as a function of the rainfall erosivity categories was evaluated (Table 4). The two highest EI30 categories had only 11 rainfall events, close to $10 \%$ of the total, but represented $50 \%, 48 \%$ and $44 \%$ of the total volume lost as runoff in the L0, L1 and L2 rates, respectively. Most of the rainfall events had low erosivity values, and there was no difference in the runoff volume among treatments for these events.

Two extreme events stand out, with erosivity above $300 \mathrm{MJ} \mathrm{mm} \mathrm{ha}^{-1} \mathrm{~h}^{-1}$, and were responsible for approximately $25 \%$ of the total runoff volume. These events happened on November 29, 2000 (total rainfall of $76.7 \mathrm{~mm}$ with a return period of two years and a maximum 30 minute intensity of $114.4 \mathrm{~mm} \mathrm{~h}^{-1}$ with a return period of thirty years) and on February 18, 2003 $(127.0 \mathrm{~mm}$ with a return period of twenty years and $81.5 \mathrm{~mm} \mathrm{~h}^{-1}$ with a return period of three years).

The rainfall events on 11/29/2002 and 02/18/ 2003 can be considered as extreme due to the $30 \mathrm{~min}$ utes maximum intensity and the total volume of rainfall, respectively. Since the experiment was carried out under natural rainfall, it was possible to evaluate the impact of these extreme events on the water and sediment loss from the runoff plots. The 29/11/2002 rainfall event had a very high intensity, with a different behaviour than 
the other events, which explains the large dispersion of points on Figure 1a, and the better correlation between runoff volume and the EI30 index.

\section{Sediment volume}

Most of sediment losses generally occur in two or three rainfall events (Edwards \& Owens, 1991). In this study, only two rainfall events represent most of the sediment losses $(90 \%)$ in the period studied. The sewage sludge application resulted in a reduction of the sediment loss by runoff in the years studied of $30 \%$ and $50 \%$ in the $\mathrm{L} 1$ and $\mathrm{L} 2$ rates (Table 5), respectively. These values are close to those reported by Mostaghimi et al. (1989) in a study with sewage sludge application, where there was a $51.5 \%$ reduction in the sediment losses in comparison to the control plots, with no sewage application. The reduction of erosion with sewage sludge application is a function of the changes in the physical properties of the soil, with an increased water infiltration (Jorge et al., 1991), but also by the increase in crop growth, with more soil cover and consequent a rain drop protection.
There was no difference $(p<0.05)$ between the treatments. This was probably due to the high variability in the measured values, with high minimum differences. Erosion is not a uniform process, and a large number of replications would be necessary for a better representation of the population studied.

In the extreme rainfall event that occurred on $11 / 29 / 2002$, eleven days after the sewage sludge application, two conditions significantly affected runoff. First, since it happens at the beginning of the crop cycle, there was little ground cover. Second, the soil had just been tilled for the sludge and fertilizer incorporation. These factors made the plots more susceptible to erosion and possibly masked in some of the replications the potential for decrease in sediment loss in the sewage applied treatments. Loch et al. (1995) studied the effect of surface application of different rates of sewage sludge on a field plot with a rainfall simulator, and did not find differences in sediment loss between the treatments, possibly due to the high variability in sediment volume between replications. Considering absolute values, without application of statis-

Table 4 - Runoff water volume in 120 rainfall events in 2001/2002 and 2002/2003, classified according to rainfall erosivity $\left(\mathrm{EI}_{30}\right)$, in the sewage sludge application rates of $0(\mathrm{~L} 0), 10.2(\mathrm{~L} 1)$ and $20.5(\mathrm{~L} 2) \mathrm{Mg} \mathrm{ha}^{-1}$.

\begin{tabular}{lcccc}
\hline \multirow{2}{*}{ EI30 } & \multirow{2}{*}{ Number of events } & \multicolumn{3}{c}{ Runoff volume } \\
\cline { 3 - 4 } & & L0 & L1 & L2 \\
\hline MJ mm ha $^{-1} \mathrm{~h}^{-1}$ & 59 & $33.3 \mathrm{a}^{\dagger}$ & $30.0 \mathrm{a}$ & $30.2 \mathrm{a}$ \\
0 & 28 & $62.3 \mathrm{a}$ & $48.5 \mathrm{a}$ & $46.2 \mathrm{a}$ \\
$1-50$ & 22 & $109.0 \mathrm{a}$ & $69.7 \mathrm{~b}$ & $66.3 \mathrm{~b}$ \\
$50.1-150$ & 9 & $89.6 \mathrm{a}$ & $51.9 \mathrm{~b}$ & $48.3 \mathrm{~b}$ \\
$150.1-300$ & 2 & $108.0 \mathrm{a}$ & $77.3 \mathrm{ab}$ & $60.2 \mathrm{~b}$ \\
$>300$ & 120 & $401.9 \mathrm{a}$ & $277.3 \mathrm{a}$ & $251.2 \mathrm{a}$ \\
\hline Total & &
\end{tabular}

${ }^{\top}$ Mean values followed by the same letter are not different $(p<0.05)$.

Table 5 - Runoff sediment losses, average of four replications, in the sewage sludge application rates of 0 (L0), 10.2 (L1) and 20.5 (L2) $\mathrm{Mg} \mathrm{ha}^{-1}$, in the seven rainfall events which produced sediment losses.

\begin{tabular}{|c|c|c|c|c|c|}
\hline \multirow{2}{*}{ Date } & \multirow{2}{*}{ Rainfall } & \multirow{2}{*}{$\begin{array}{c}\text { Erosivity } \\
\mathrm{EI}_{30}\end{array}$} & \multicolumn{3}{|c|}{ Sediment weight } \\
\hline & & & L0 & L1 & L2 \\
\hline & $\mathrm{mm}$ & & \multicolumn{3}{|c|}{$-1 \mathrm{ha}^{-1}-1$} \\
\hline $12 / 24 / 2001$ & 40.6 & 38 & 1.09 & 0.08 & 0.29 \\
\hline $1 / 25 / 2002$ & 14.2 & 0 & 0.09 & 0 & 0 \\
\hline $11 / 29 / 2002$ & 77.0 & 1700 & 6.52 & 6.93 & 4.16 \\
\hline $1 / 11 / 2003$ & 34.1 & 211 & 0.30 & 0 & 0 \\
\hline $1 / 12 / 2003$ & 28.6 & 115 & 0.87 & 0 & 0 \\
\hline $1 / 13 / 2003$ & 27.0 & 101 & 0.26 & 0 & 0 \\
\hline $2 / 18 / 2003$ & 130.8 & 2137 & $3.34 \mathrm{a}^{\dagger}$ & $1.80 \mathrm{ab}$ & $0.88 \mathrm{~b}$ \\
\hline \multicolumn{3}{|c|}{ Total (2001/2002 and 2002/2003) } & 12.48 & 8.82 & 5.77 \\
\hline
\end{tabular}

${ }^{\dagger}$ Mean values followed by the same letter are not different $(p<0.05)$. 
tical tests, Bossche et al. (2000) observed a decrease in the volume of sediment loss, of $1,200 \mathrm{~kg} \mathrm{ha}^{-1}$ to $500 \mathrm{~kg} \mathrm{ha}^{-1}$, as a function of sewage sludge application.

Except for the two mentioned extreme events, the sediment losses were very low in the plots with sewage sludge application, indicating that the erosion risk with sludge application would be minimized if soil conservation practices will be applied. Nevertheless, it is important to point out the risk associated with the high sediment losses caused by extreme events in areas where a waste with contaminant capacity has been utilized. Therefore, it is essential to minimize the potential for runoff losses when planning sewage sludge application. The trends in the volume of runoff water and sediment from rainfall in the two-year period studied lead to the conclusion that the sewage sludge application resulted in a reduction of the runoff erosion losses, as reported by Aguilar \& Loftin (1991) and Joshua et al. (1998).

\section{Trace metal load in the water and sediment}

The trace metal concentration in the runoff water was analyzed for 72 of the 120 rainfall events in the period (Table 6). The average $\mathrm{Cu}$ and $\mathrm{Ni}$ concentration in runoff water varied little among treatments. $\mathrm{Zn}$ concentration in the water was affected by the sludge application rates, with higher concentrations in the areas that received the highest rate. This concentration increase reflects the increase in the soil surface layer $\mathrm{Zn}$ amount as described in this same experiment by Galdos et al. (2004). The limits for acceptable concentrations of trace metals in the current environmental legislation in Brazil are very restrictive. The $\mathrm{Ni}$ and $\mathrm{Zn}$ concentration in the runoff water in all three treatments exceeded the limit values of 0.025 and $0.001 \mathrm{mg} \mathrm{L}^{-1}$, respectively. The runoff concentration of $\mathrm{Cu}$ was lower than the limit established in the legislation, $0.500 \mathrm{mg} \mathrm{L}^{-1}$ (CETESB, 1999).

The exchangeable content of $\mathrm{Cu}, \mathrm{Ni}$ and $\mathrm{Zn}$ in the sediment was higher where the highest rate of sewage sludge was applied (Table 6). In spite of this fact, only the $\mathrm{Zn}$ concentration increased. These results were compared to the limits proposed by Long et al. (1995), used by the US National Sediment Institute, in the risk assessment of contamination of water bodies by runoff sediment. According to these standards, zinc concentrations higher than $150 \mathrm{mg} \mathrm{kg}^{-1}$ would indicate a moderate risk for the aquatic biota. Although the concentrations observed in this study were lower than this limit, the cumulative effects of annual sewage sludge application could lead to environmental damage in the water bodies receiving this kind of runoff water and sediment.

Table 6 - Average values for water runoff concentration of copper $(\mathrm{Cu})$, nickel $(\mathrm{Ni})$ and zinc $(\mathrm{Zn})$, exchangeable content and total content in sediment subsequent to application rates of 0 (L0), 10.2 (L1) and 20.5 (L2) $\mathrm{Mg} \mathrm{ha}^{-1}$ of sewage sludge in two years.

\begin{tabular}{|c|c|c|c|c|c|c|c|c|}
\hline \multicolumn{3}{|c|}{$\mathrm{CU}$} & \multicolumn{3}{|c|}{$\mathrm{Ni}$} & \multicolumn{3}{|c|}{$\mathrm{Zn}$} \\
\hline L0 & L1 & L2 & L0 & $\mathrm{L} 1$ & L2 & L0 & L1 & L2 \\
\hline \multicolumn{9}{|c|}{ Concentration in runoff, $\mathrm{mg} \mathrm{L}^{-1}$} \\
\hline 0.033 & 0.031 & 0.032 & 0.058 & 0.064 & 0.061 & $0.064 \mathrm{a}$ & $0.085 \mathrm{ab}$ & $0.091 \mathrm{~b}$ \\
\hline \multicolumn{9}{|c|}{ Exchangeable content in sediment, $\mathrm{mg} \mathrm{dm}^{-3}$} \\
\hline 6.3 & 11.2 & 15.9 & $0.1 \mathrm{a}^{\dagger}$ & $0.4 \mathrm{ab}$ & $0.9 \mathrm{~b}$ & $6.6 \mathrm{a}$ & $25.8 \mathrm{ab}$ & $57.8 \mathrm{~b}$ \\
\hline \multicolumn{9}{|c|}{ Total content in sediment, $\mathrm{mg} \mathrm{kg}^{-1}$} \\
\hline 114 & 110 & 101 & 31 & 27 & 25 & $78 \mathrm{a}$ & $100 \mathrm{ab}$ & $131 \mathrm{~b}$ \\
\hline
\end{tabular}

†Mean values followed by the same letter are not different $(p<0.05)$.

Table 7 - Load of copper $(\mathrm{Cu})$, nickel $(\mathrm{Ni})$ and zinc $(\mathrm{Zn})$ in the runoff water and in the sediment as exchangeable load and total load in the sewage sludge application rates of 0 (L0), 10.2 (L1) and 20.5 (L2) Mg ha', for the two-year period.

\begin{tabular}{|c|c|c|c|c|c|c|c|c|}
\hline \multicolumn{3}{|c|}{$\mathrm{CU}$} & \multicolumn{3}{|c|}{$\mathrm{Ni}$} & \multicolumn{3}{|c|}{$\mathrm{Zn}$} \\
\hline L0 & L1 & $\mathrm{L} 2$ & L0 & L1 & $\mathrm{L} 2$ & L0 & L1 & $\mathrm{L} 2$ \\
\hline \multicolumn{9}{|c|}{ Load in runoff, $\mathrm{g} \mathrm{ha}^{-1}$} \\
\hline 0.205 & 0.121 & 0.105 & 0.282 & 0.225 & 0.159 & 0.392 & 0.338 & 0.355 \\
\hline \multicolumn{9}{|c|}{ Load of exchangeable metals in sediment, $\mathrm{g} \mathrm{ha}^{-1}$} \\
\hline 62 & 77 & 72 & 1 & 3 & 4 & 64 & 179 & 262 \\
\hline \multicolumn{9}{|c|}{ Load of total metals in sediment, $\mathrm{g} \mathrm{ha}^{-1}$} \\
\hline 114 & 110 & 101 & 31 & 27 & 25 & $78 \mathrm{a}$ & $100 \mathrm{ab}$ & $131 \mathrm{~b}$ \\
\hline
\end{tabular}



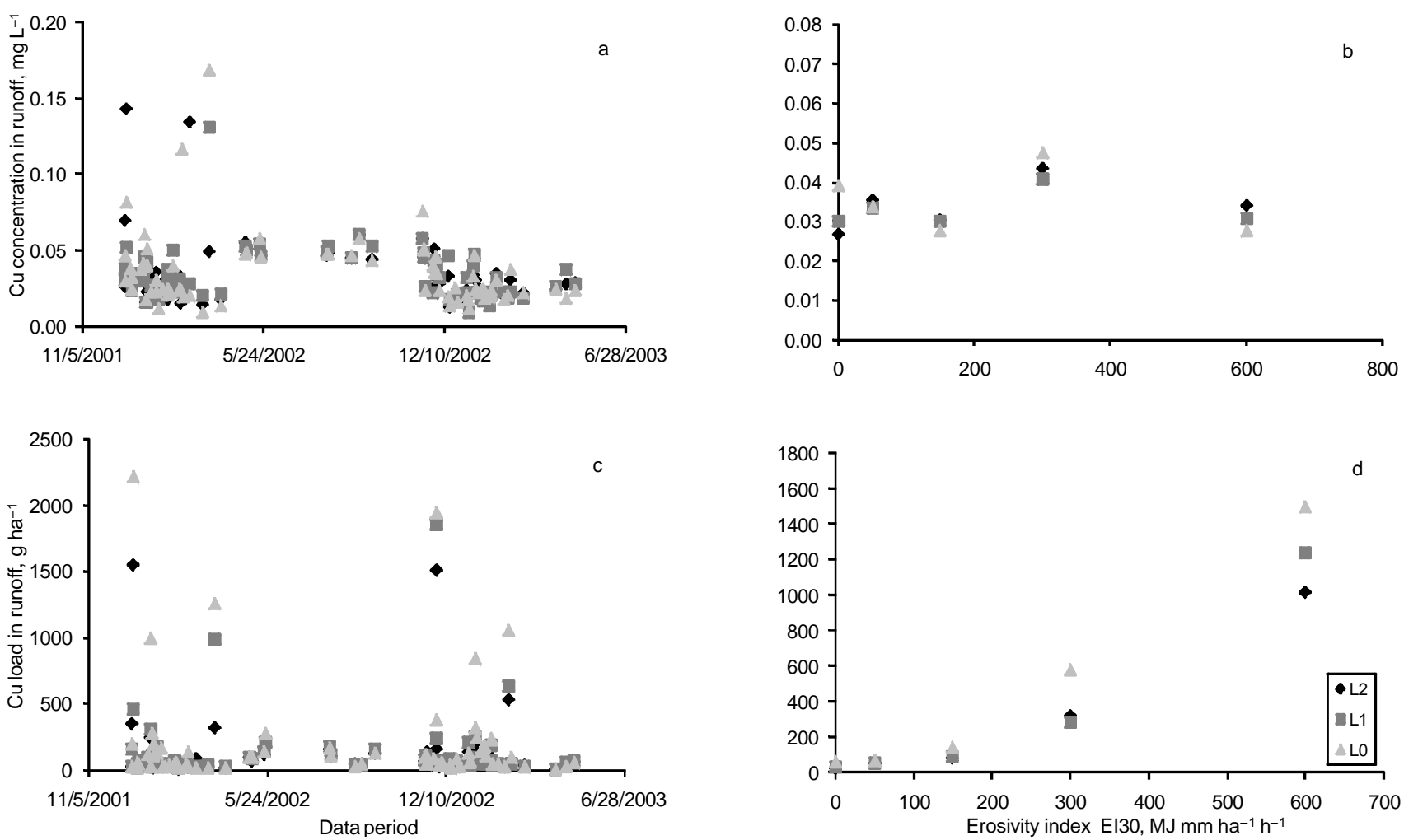

Figure 2 - Copper concentration and load in the runoff water as a function of (a and c) time and (b and d) EI ${ }_{30}$ classes, respectively, in the sewage sludge application rates of 0 (L0), 10.2 (L1) and 20.5 (L2) $\mathrm{Mg} \mathrm{ha}^{-1}$ application rates of 0 (L0), 10.2 (L1) and 20.5 (L2) $\mathrm{Mg} \mathrm{ha}^{-1}$.
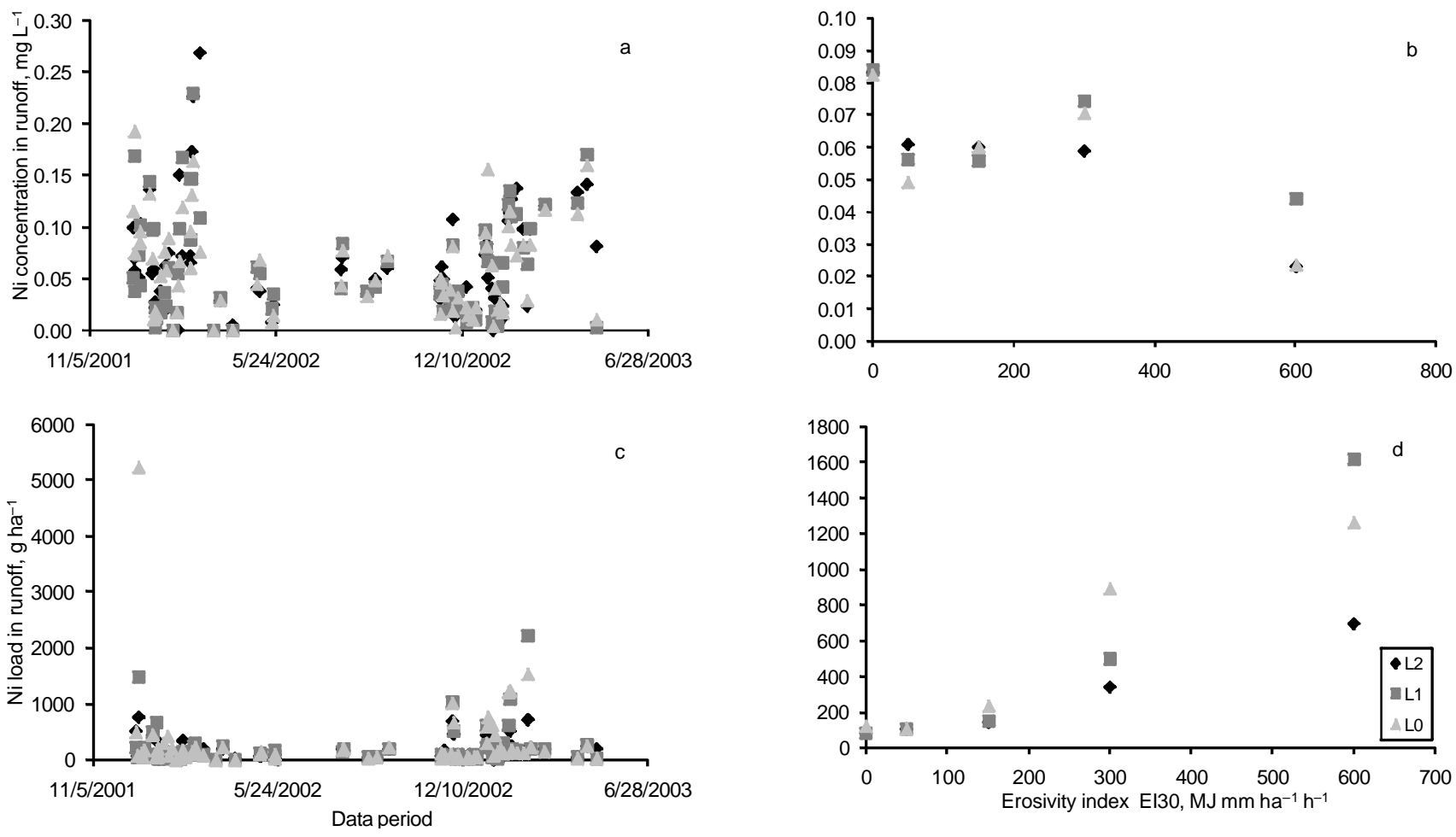

Figure 3 - Nickel concentration and load in the runoff water as a function of (a and c) time and (b and d) EI 30 classes, respectively, in the sewage sludge application rates of 0 (L0), 10.2 (L1) and 20.5 (L2) $\mathrm{Mg} \mathrm{ha}^{-1}$. 

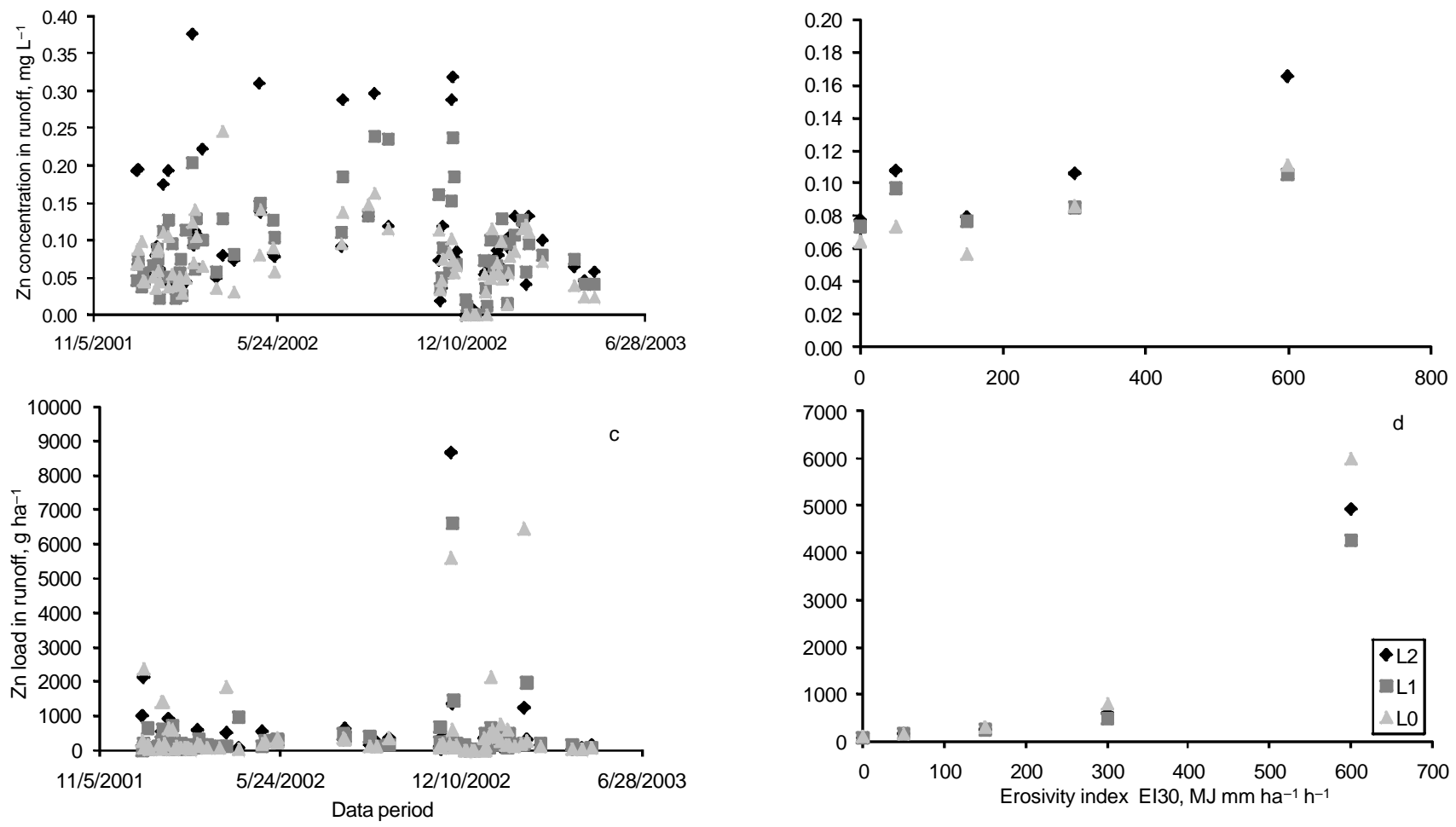

Figure 4 - Zinc concentration and load in the runoff water as a function of (a and c) time and (b and d) EI ${ }_{30}$ classes, respectively, in the sewage sludge application rates of 0 (L0), 10.2 (L1) and 20.5 (L2) $\mathrm{Mg} \mathrm{ha}^{-1}$.

The total load of metals in the runoff was calculated from the volume of water and sediment and the metal concentration (Table 7). There was a trend for lower loads in the areas with higher rates of sewage sludge, although the concentration was higher, that was related to the high runoff volume in the plots without sewage sludge application. Therefore, the trace metal load was more influenced by the runoff volume than by the concentration, which represents an important point to be considered in terms of contamination of water bodies.

The concentration and load of $\mathrm{Cu}, \mathrm{Ni}$ and $\mathrm{Zn}$ are in Figures 2, 3 and 4, respectively, separated by rainfall events and by $\mathrm{EI}_{30}$ categories. There was large variability in the runoff trace metal concentration, with no direct relationship with rainfall volume, time after sludge application and $\mathrm{EI}_{30}$ values. The trace metals load transported in the runoff is directly related to the volume and intensity of rainfall events, represented by the $\mathrm{EI}_{30}$ values.

The total load of trace metals was transported mostly by sediment, as compared to the water runoff losses (Table 7). Considering all events, the total content of metals transported by sediment was proportional to sediment yield during the two years. On plots with no sewage sludge application, the load of total metals was higher. Once again, this was caused by the higher sediment losses on this treatment, as showed on Table
5. However, the load of exchangeable metals was higher on plots with sewage sludge, and this was related to concentration of metals on sediment (Table 6).

\section{CONCLUSIONS}

Sewage sludge application in soil reduced total volume of sediment and water in the surface runoff and, as a result, load of the total amount trace metals was not altered by the waste utilized in the two years covered by the study.

There was an increase in the load of exchangeable $\mathrm{Cu}, \mathrm{Ni}$ and $\mathrm{Zn}$ in the sediment transported by runoff after sewage sludge application.

Application of sewage sludge increased the exchangeable $\mathrm{Zn}$ concentration in runoff and increased exchangeable $\mathrm{Zn}$ transported by water and sediment.

The transport of $\mathrm{Cu}, \mathrm{Ni}$ and $\mathrm{Zn}$ was mainly due to sediment losses occurring in a few highly erosive rainfall events in the period studied.

\section{ACKNOWLEDGMENTS}

To FAPESP (Fundação de Amparo à Pesquisa do Estado de São Paulo) for funding this research $\left(\mathrm{n}^{\circ}\right.$. 01/10617-8) and Eng. Fernando Carvalho Oliveira, for providing the sewage sludge used in the experiment. To $\mathrm{CNPq}$ for Dr. Otávio Antonio de Camargo granting. 


\section{REFERENCES}

ABREU, M.F.; ABREU, C.A.; ANDRADE, J.C. Determinação de fósforo, potássio, cálcio, magnésio, enxofre, cobre, ferro, manganês, zinco, níquel, cádmio, cromo e chumbo em ácido nítrico usando métodos de US-EPA. In: RAIJ, B. van; ANDRADE, J.C.; CANTARELlA, H.; QUAGGIO, J.A. (Ed) Análise química para avaliação da fertilidade de solos tropicais. Campinas: Instituto Agronômico, 2001. p.151-161.

AGUILAR, R.; LOFTIN, S.R. Sewage sludge application in semiarid grasslands: effects on runoff and surface water quality. In: ANNUAL NEW MEXICO WATER CONFERENCE, 36., Las Cruces, 1991. Proceedings. New Mexico: Water Resources Research Institute, 1991. p.101-111. (WRRI Report, 265).

BERTON, R.S. Riscos de contaminação do agroecossistema com metais pesados. In: BETTIOL, W.; CAMARGO, O.A. (Ed.). Impacto ambiental do uso agrícola do lodo de esgoto. Jaguariúna: Embrapa Meio Ambiente, 2000. p.259-268.

BERTONI, J.; LOMBARDI NETO, F. Conservação do solo. São Paulo: Ícone, 1990. 355p.

BOSSCHE, H.V.; AUDIC, J.M.; HUHYARD, A.; GASCUELODOUX, C.; TROLARD, F.; BOURRIE, G. Phosphorus losses from sewage sludge disposed on a field: evidence from storm event simulations. Water Science and Technology, v.42, p. 179-186, 2000 .

CANTARELlA, H.; TRIVELIN, P.C.O. Determinação de nitrogênio total em solo. In: RAIJ, B. van; ANDRADE, J.C.; CANTARElla, H.; QUAGGIO, J.A., (Ed.) Análise química para avaliação da fertilidade de solos tropicais. Campinas: Instituto Agronômico, 2001. 285p.

COMPANHIA DE TECNOLOGIA DE SANEAMENTO AMBIENTAL - CETESB. Aplicação de biossólidos de sistemas de tratamento biológico em áreas agrícolas: critérios para projeto e operação; manual técnico. São Paulo: Cetesb, 1999. 33p.

CRITCHFIELD, H.J. General climatology. Englewood Cliffs: Prentice-Hall, 1960. 465p.

EDWARDS, W.M.; OWENS, L.B. Large storm effects on total soil loss. Journal of Soil and Water Conservation, v.46, p.75$78,1991$.

ELLIOT, H.A. Land application of municipal sewage sludge. Journal of Soil and Water Conservation, v.41, p.5-10, 1986.

EVANGELOU, V.P. Environmental soil and water chemistry. New York: John Wiley, 1998. 564p.

GALDOS, M.V.; DeMARIA, I.C.; CAMARGO, O.A. Atributos químicos e produção de milho em um latossolo vermelho eutroférrico tratado com lodo de esgoto. Revista Brasileira de Ciência do Solo, v.28, p.569-577, 2004.

HARRIS-PIERCE, R.L.; REDENTE, E.F.; BARBARICK, K.A. Sewage sludge application effects on runoff water quality in a semiarid grassland. Journal of Environmental Quality, v.24, p.112-115, 1995 .
JORGE, J.A.; CAMARGO, O.A.; VALADARES, J.M.A.S. Condições físicas de um latossolo vermelho escuro, quatro anos após a aplicação de lodo de esgoto e calcário. Revista Brasileira de Ciência do Solo, v.15, p.237-240, 1991 .

JOSHUA, W.D.; MICHALK, D.L.; CURTIS, I.H.; SALT, M.; OSBORNE, G.J. The potential for contamination of soil and surface waters from sewage sludge (biosolids) in a sheep grazing study, Australia. Geoderma, v.84, p.135-156, 1998.

KELLING, K.A.; PETERSON, A.E.; WALSH, L.M. Effect of wastewater sludge on soil moisture relationships and surface runoff. Journal of Water Pollution Control Federation, v.49, p.1698-1703, 1977.

KLADIVKO, E.J.; NELSON, D.W. Surface runoff from sludgeamended soils. Journal of the Water Pollution Control Federation, v.51, p.100-110, 1979.

LOCH, R.J.; COSTANTINI, A.; BARRY, G.A.; BEST, E.K. Evaluation of the potential to dispose of sewage sludge. II. Potential for off-site movements of solids and solutes. Australian Journal of Soil Research, v.33, p.1053-1062, 1995.

LOMBARDI NETO, F.; BERTONI, J. Erodobilidade de solos paulistas. Campinas: Instituto Agronômico, 1975. 12p. (Boletim Técnico, 27).

LOMBARDI NETO, F.; MOLDENHAUER, W.C. Erosividade da chuva: sua distribuição e relação com as perdas de solo em Campinas, SP. Bragantia, v.51, p.189-196, 1992.

NAVAS, A.; BERMUDEZ, F.; MACHIN, J. Influence of sewage sludge application on physical and chemical properties of Gypsisols. Geoderma, v.87, p.123-135, 1998.

MOSTAGHIMI, S.; DEIZMAN, M.M.; DILlAHA, T.A.; HEATWOLE, C.D. Impact of land application of sewage sludge on runoff water quality. Transactions of the ASAE, v.32, p.491496, 1989.

QUINTON, J.N.; CATT, J.A.; HESS, T.M. The selective removal of phosphorus from soil: is event size important? Journal of Environmental Quality, v.30, p.538-545, 2001.

RAIJ, B. van; ANDRADE, J.C.; CANTARELLA, H.; QUAGGIO, J.A. Análise química para avaliação da fertilidade de solos tropicais. Campinas: Instituto Agronômico, 2001. 285p.

SAS INSTITUTE. SAS/STAT software: changes and enhancements through release 6.12. Cary: SAS Institute, 1997.

WILSON, S.C.; DUARTE-DAVIDSON, R.; JONES, K.C. Screening the environment fate of organic contaminants in sewage sludges applied to agricultural soil. 1. The potential for downward movement to groundwaters. Science of the Total Environment, v.185, p.45-57, 1996.

WISCHMEIER, W.H.; SMITH, D.D. Predicting rainfall erosion losses: a guide to conservation planing. Washington, D.C.: USDA, 1978. 58p. (Agricultural Handbook, 537).

Received September 21, 2007

Accepted October 13, 2008 